\title{
The Rationality of Antibiotics Use on Acute Diarrhea to Pediatric Inpatients in the Fatmawati Hospital for 2018-2019 period
}

\author{
Nisa Najwa Rokhmah ${ }^{1 *}$, Yovania Grace Priskila Manuel ${ }^{1}$, Ema Nillafita Putri Kusuma ${ }^{1}$, Naufal \\ Muharram Nurdin ${ }^{2}$ \\ ${ }^{1}$ Jurusan Farmasi, Fakultas Matematika dan Ilmu Pengetahuan Alam, Universitas Pakuan, Bogor, Indonesia. \\ ${ }^{2}$ Departemen Gizi Masyarakat, FEMA IPB, Indonesia \\ *E-mail: nisanajwarokhmah@gmail.com
}

Article Info:

Received: 10 November 2021

in revised form: 24 January 2022

Accepted: 15 Februari 2022

Available Online: 1 March 2022

Keywords:

Diarrhea

Rationality of antibiotics

Gyssens flowchart method.

Corresponding Author:

Nisa Najwa Rokhmah

Prodi Farmasi

Fakultas MIPA

Universitas Pakuan Bogor

Indonesia

email:

nisanajwarokhmah@gmail.com

\begin{abstract}
Background: Diarrhea is characterized by an increase in the frequency of bowel movements more than three times a day. This disease has a fairly high incidence rate in Indonesia, especially in children. One of the causes of diarrhea is a bacterial infection, therefore it needs to be treated with antibiotics. Several studies show that there are still many antibiotics that are used irrationally. It is necessary to analyze the rationality of the use of antibiotics in pediatric patients with diarrhea using the Gyssens method Objectives: This study is to ascertain the profile of acute diarrhea pediatric patients characteristic and evaluate antibiotics rationality with Gyssens method. Moreover, the purpose of this study is to analyze the factors that influence the rationality of the use of antibiotics in the inpatient pediatric acute diarrhea installation of Fatmawati Hospital 2018-2019 period. Material and Methods: This study is descriptive observational research. The study design was cross-sectional with retrospective data collection which was analysed then qualitatively with the Gyssens flow method Results: The result showed 54,29\% antibiotics usde appropriately and rational. The irrational use of antibiotics was $45.7 \%$. The results of statistical analysis with chi-square show a significant relationship between the rationality of antibiotics and the type of antibiotic $(\rho=0.000<0.05)$ and multiple logistic regression analysis showed that the route of drug administration $(\rho=0.000<0.05)$ affected the rationality of antibiotics use. Conclusions: Less than $50 \%$ of the patients received irrational treatment according to the Gyssen flow chart and according to the results of statistical analysis, the type of antibiotic and the route of drug administration affected the rationality of antibiotics.
\end{abstract}

How to cite (APA $6^{\text {th }}$ Style):

Rokhmah, N. N., Manuel, Y. G. P., Kusuma, E. N. P., Nurdin, N. M. (2022). The Rationality of Antibiotics Use on Acute Diarrhea to Pediatric Inpatients in the Fatmawati Hospital for 2018-2019 period. Jurnal Farmasi Galenika :Galenika Journal of Pharmacy (e-Journal), 8(1), 10-21. doi:10.22487/j24428744.2022.v8.i2.15601 


\begin{abstract}
ABSTRAK
Latar Belakang: Diare merupakan suatu penyakit yang memiliki gejala yang ditandai dengan peningkatan frekuensi buang air besar menjadi lebih dari tiga kali dalam sehari. Penyakit ini memiliki angka kejadian yang cukup tinggi di Indonesia terutama pada anak-anak. Diare dapat terjadi salah satunya karena infeksi bakteri sehingga perlu diatasi dengan pemberian antibiotik. Beberapa penelitian menunjukkan masih banyaknya antibiotik yang digunakan secara tidak rasional. Sehingga perlu dilakukan analisis rasionalitas penggunaan antibiotik pada pasien anak yang mengalami diare dengan metode Gyssens. Tujuan: Tujuan penelitian ini adalah mengetahui karakteristik pasien diare akut pediatri, mengevaluasi rasionalitas penggunaan antibiotik secara kualitatif menggunakan metode gyssens dan menganalisis faktor-faktor yang mempengaruhi rasionalitas penggunaan antibiotika pada pasien diare akut pediatri rawat inap di Rumah Sakit Umum Pusat Fatmawati periode 2018-2019. Bahan dan Metode: Penelitian ini adalah jenis penelitian observasional deskriptif. Rancangan penelitian yang dipakai adalah cross sectional dengan pengambilan data secara Retrospektif yang dianalisis secara kualitatif dengan metode alur Gyssens. Hasil: Berdasarkan penelitian yang telah dilakukan hasil dari analisis kualitatif dengan metode Gyssens didapatkan hasil penggunaan antibiotika tepat dan rasional sebesar 54,29\% dan yang tidak rasional sebesar $45,61 \%$. Pada hasil analisis statistik dengan chi-square menunjukan bahwa terdapat hubungan signifikan antara rasionalitas antibiotika dengan jenis antibiotika $(\rho=0,000<0,05)$ yang digunakan dan pada hasil uji statistik dengan analisis regresi logistik berganda menunjukan bahwa rute pemberian obat $(\rho=0,000<0,05)$ mempengaruhi rasionalitas penggunaan antibiotika. Kesimpulan: berdasarkan penelitian kurang dari 50\% pasien yang dianalisis mendapatkan pengobatan yang tidak rasional menurut alur gyssen dan menurut hasil analisis statistik, jenis antibiotik serta rute pemberian obat mempengaruhi rasionalitas antibiotik
\end{abstract}

Kata kunci: Diare; Rasionalitas penggunaan antibiotika; Metode Gyssens

\title{
INTRODUCTION
}

Diarrhea is still becoming a common disease for citizens of developing countries such as Indonesia because of the high mortality and incidence rate. According to the data, 278.736 people experienced diarrhea or $80.22 \%$. The assumption of the number of diarrhea in the three largest urban areas in South Jakarta at $87.85 \%$, North Jakarta at $86.78 \%$ and East Jakarta at $83.71 \%$ (Dinkes, 2017).

Diarrhea can occur due to infectious factors, such as viral, bacterial and parasitic infections. And noninfectious factors, for example: food, hygiene, nutritional, socio-economic and environmental conditions. Diarrhea is dangerous if it causes dehydration, lack of fluids and electrolytes condition lead to heart rhythm disturbances, lower consciousness and even death. Treatment of acute diarrhea in children consists of oral rehydration, zinc, diet, probiotics and antibiotics (World Gastroenterology Organisation, 2012). Antibiotics are used to treat infectious diseases caused by bacteria. Approximately $40-62 \%$ found irrational use of antibiotics and in health services by $30-80 \%$ not according to indications. Inappropriate and irrational use of antibiotics could cause bacterial resistance to antibiotics, lastly impact mortality and the incidence of a disease. Resistance could be prevented by using antibiotics appropriately and rationally to increase the quality of health services.

According to the Ministry of Health (2015), Gyssens flow chart could be used to analyze antibiotic rationality. Gyssens method has the advantage that the results obtained are more precise and detailed. The Gyssens method itself is divided into category 0 (appropriate and rational use), category I (incorrect 
administration time), category II A (inappropriate administration dose), category II B (inappropriate administration interval), category II C (inappropriate route of administration), category III A (too long administration), category III B (too short administration), category IV A (wrong choice of antibiotic because there are more effective antibiotics than the patients used), category IV B (inappropriate selection of antibiotics because there are other antibiotics safer), category IV C (inappropriate selection of antibiotics because there are other cheaper antibiotics), category IV D (wrong choice of antibiotics because there are other, more specific antibiotics with a narrower spectrum), category V (use of antibiotics without the presence of indications), and category VI (incomplete medical record and could not be evaluated).

This experiment is qualitative research on the rationality of antibiotics using the Gyssens method in pediatric patients suffering from acute diarrhea in the inpatient ward of the Fatmawati General Hospital for the period 2018-2019, to see whether the use of antibiotics in the hospital is rational or not.

\section{MATERIAL AND METHODS}

\section{Materials}

Research materials in this study were patient medical records, data collection sheets, Gyssens flowcharts, and literature as evaluation references. The ethical review was carried out before the study began and was approved by the Fatmawati Center General Hospital Research Ethics Commission with number 29/KPP/IV/2021

\section{Methods}

The study was conducted from February to April 2021 at Fatmawati Central General Hospital, South Jakarta City, DKI Jakarta.This research is descriptive observational research using a cross-sectional research design.

Data collection was carried out retrospectively, which was analyzed qualitatively with the Gyssens flow method through medical records in pediatric inpatients aged 0-19 years with acute diarrhea in Fatmawati Hospital years 2018-2019. In this study Pediatric Dosage Handbook (Carol K. Taketomo, et al., 2011) and Drug Information Handbook (Lacy, et al., 2010) was used as evaluation reference.

The sampling technique was arranged as purposive sampling. The minimal samples required by Slovin is 93. This research obtain 105 pediatric patients that meet the inclusion criteria.

The data analysis used was descriptive analysis to describe the use of antibiotics, and the data were collected retrospectively. The data obtained were checked for completeness, and there were no errors in 
data entry. Then an evaluation was carried out to see the rationality of antibiotics using the Gyssens flow chart and the category of assessment of the use of Gyssens antibiotics.

The data analyzed using SPSS (Statistical Program for Social Science) 20 edition. Univariate analysis was performed to see the frequency and percentage distribution in pediatric patients with diarrheal infections, based on age, gender, length of hospitalization, polypharmacy, comorbidities, antibiotics used, route of administration, duration of administration. Furthermore, statistical analysis was carried out using chi-square to see the relationship between the rationality of the use of antibiotics and the type of antibiotics used. Multiple logistic regression analysis was used to determine the effect of confounding variables on the rationality of antibiotic use.

\section{RESULTS AND DISCUSSION}

This study was conducted to understand antibiotic prescribing profiles and patient characteristics in pediatric acute diarrhea patients hospitalized at Fatmawati Central General Hospital in 2018-2019. Furthermore, evaluate the antibiotics rationality qualitatively using the Gyssens method and determine factors influence the use of antibiotics - rationality of a drug. The data were taken retrospectively. From the results of the medical record data study, it was found that 105 patients met the inclusion criteria.

\section{Patient Characteristics}

Patient characteristics are characteristics by a person to distinguish that person from other people. The patient characteristics in this study consisted of age, gender, length of hospitalization, polypharmacy, and comorbidities.

Table 1 Characteristics of Pediatric Inpatients with Acute Diarrhea at Fatmawati Hospital for the 20182019 Period

\begin{tabular}{l|c}
\hline & $\mathbf{n}(\%)$ \\
\hline Age & $72(68,57)$ \\
Baby $: 0-1$ years old & $31(29,52)$ \\
Child $: 2-10$ years old & $2(1,91)$ \\
Teenager $: 11-19$ years old & \\
Gender & $61(58,10)$ \\
Boys & $44(41,90)$ \\
Girls & $99(94,29)$ \\
Length of stay & $6(5,71)$ \\
$<14$ days & \\
Polipharmacy & $55(52,38)$ \\
Yes & $50(47,62)$ \\
No & \\
Comorbid* & $22(16,54)$ \\
Malnutrition & $1(0,75)$ \\
Hypoalbuminemia & $20(15,04)$ \\
Hyponatremia & $23(17,30)$ \\
Hypokalemia & $2(1,50)$ \\
Intake difficulties &
\end{tabular}




\begin{tabular}{l|c} 
Mild febrile convulsion & $2(1,50)$ \\
Complex febrile convulsion & $7(5,26)$ \\
Cow’s milk allergy & $7(5,26)$ \\
Anemia & $19(14,30)$ \\
Defect septum ventrikel (VSD) & $2(1,50)$ \\
Delayed development & $7(5,26)$ \\
Epilepsy & $7(5,26)$ \\
Cholitis & $1(0,75)$ \\
Colostomy & $3(2,26)$ \\
Shock Hypovolemic & $8(6,02)$ \\
Vomitus & $2(1,50)$ \\
\hline
\end{tabular}

*Patient could have more than one comorbid

Based on the table 1, it is known that acute diarrheal disease in pediatric patients is mainly experienced by patients aged 0-1 years, followed by patients aged 2-10 years and patients aged 11-19 years having minor acute diarrhea. This result is in line with previous data that the highest incidence of diarrhea occurred in toddlers (1-4 years) at 16.7\% (Badan Penelitian dan Pengembangan Kesehatan Departemen Kesehatan Republik Indonesia, 2008). According to the Ministry of Health (2011) In Indonesia, diarrhea occurs around 70-89\% and generally attacks children under five years. It is reported that diarrhea in children is the second leading cause of death after pneumonia (IVAC, 2014). Those could happen because the immune system is not in optimal condition that susceptible to bacteria. Not all antibiotics can be used for pediatrics because the ADME (Absorption, Distribution, Metabolism, and Elemination) process in pediatrics and adults is different. It could cause side effects and possibly higher adverse effects due to bacterial infection (Dipiro et al., 2015).

The results showed that most of the patients were boys compared to girls. However, in general, diarrhea is not affected by gender because diarrhea in children is caused by the immune system, nutritional status, diet, hygiene, and physical activity. In men, the risk of diarrhea is higher because it is influenced by physical activity (Astaqauliyah, 2010). According to Riskesdas (2013), both adult and male toddlers are more susceptible to diarrhea due to lifestyle and hygiene, which tend to be worse than women.

This study showed, the percentage of patients hospitalized for less than 14 days is higher. Diarrheal diseases can be divided into acute diarrhea ( $<14$ days), persistent diarrhea ( $>14$ days), chronic diarrhea (> 28 days). However, patients who have been hospitalized for more than 14 days could not be ascertained has persistent diarrhea because the patient data already met the inclusion criteria, which stated in the medical record that the patient was diagnosed with acute diarrhea. Those could also happen since patients diagnosed with acute liquid diarrhea are dehydrated from mild to severe dehydration. Besides that, the patient also has comorbidities such as malnutrition, epilepsy, hyponatremia, and others that require long treatment for diarrhea. In consequence, the therapy should be more careful to prevent 
interaction between drugs and unwanted side effects during the treatment process, starting from the time the patient is given treatment for the first time until he is confirmed as cured and could go home.

Polypharmacy is a patient who receives five or more kinds of drugs. There are two kinds of polypharmacy: problematic polypharmacy and non-problematic polypharmacy. In problematic polypharmacy, patients have been prescribed five or more kinds of drugs, and interaction occurs between these drugs causing adverse side effects. In comparison, non-problematic polypharmacy occurs when patients have been prescribed five or more kinds of drugs and no adverse drug interactions occur. The data shows that more pediatric patients who received polypharmacy were than non-polypharmacy. In addition, since the patients receive antibiotics, there are other drugs for acute diarrhea, such as oral rehydration therapy, zinc supplement therapy, and probiotics (World Gastroenterology Organisation , 2012). Oral rehydration therapy is a drug to treat dehydration in patients with acute, persistent, or chronic diarrhea who lack fluids in the body. Zinc supplement therapy reduces the duration, severity, frequency, and mortality of diarrhea in children aged less than five years who experience acute diarrhea. Moreover, probiotics help reduce the duration and intensity of diarrhea symptoms (Samani et al., 2014).

\section{Evaluation of Qualitative Use of Antibiotics with Gyssens Method}

A qualitative evaluation of the use of antibiotics in pediatric acute diarrhea patients hospitalized at the Fatmawati Central General Hospital for the 2018-2019 period was carried out using the Gyssens Method. Based on the evaluation results in 105 pediatric acute diarrheal patients, it is found that most of the patients received appropriate and rational antibiotic use therapy with a percentage of 54.29\%. Data distribution of antibiotics after analyzed with Gyssen method could be seen in table 2.

Table 2. Data Distribution of Antibiotics Qualitative Use with Gyssens Method in Inpatient Pediatric Acute Diarrhea at Fatmawati Hospital in 2018-2019 Period

\begin{tabular}{cl|c|c}
\hline \multirow{2}{*}{ Category } & \multirow{2}{*}{ Evaluation } & \multicolumn{2}{c}{ Patients amount (n=105) } \\
\cline { 3 - 4 } & & Amount & Percentage \\
\hline $0 \quad$ Appropriate and rational use & 57 & $54,29 \%$ \\
\hline I & Incorrect delivery time & 0 & $0,00 \%$ \\
\hline II A & Incorrect dossage & 22 & $20,95 \%$ \\
\hline II B & Incorrect time interval & 0 & $0,00 \%$ \\
\hline II C & Incorrect delivery route & 6 & $0,00 \%$ \\
\hline III A & Duration too long & 1 & $5,71 \%$ \\
\hline III B & Duration too short & $6,95 \%$ \\
\hline & $\begin{array}{l}\text { The selection of antibiotics is not appropriate } \\
\text { because there are more effective antibiotics than } \\
\text { IV A }\end{array}$ & 6 & $5,71 \%$ \\
\hline
\end{tabular}




\begin{tabular}{cl|c|c}
\hline IV B & $\begin{array}{l}\text { The selection of antibiotics is not appropriate } \\
\text { because there are safer antibiotics than others }\end{array}$ & 2 & $1,91 \%$ \\
\hline IV C & $\begin{array}{l}\text { The selection of antibiotics is not appropriate } \\
\text { because there are cheaper antibiotics than others }\end{array}$ & 4 & $3,81 \%$ \\
\hline $\begin{array}{l}\text { The selection of antibiotics is not appropriate } \\
\text { because there are antibiotics with narrower } \\
\text { spectrum }\end{array}$ & 0 & $0,00 \%$ \\
\hline IV & Antibiotic used without indication & 7 & $6,67 \%$ \\
\hline VI & $\begin{array}{l}\text { Medical records are incomplete and couldn't } \\
\text { evaluate }\end{array}$ & 0 & $0,00 \%$ \\
\hline & $\quad$ Total & $\mathbf{1 0 5}$ & $\mathbf{1 0 0} \%$ \\
\hline
\end{tabular}

Most of the irrational use of antibiotic including in category IIA (inappropriate dose). In this study the dose calculation is adjusted to the guidelines, where the dose received by the patient will be compared with the dose from the guideline which has been calculated based on the patient's weight and seen in daily use. If the dose is still within the dosage range of the guidelines, it could be said that the dose is appropriate. The dose also confirmed with the condition of the patient's clinical development, whether it is still the same or underwent improvement.

For example, in one case of cefixime, the dose given to a patient weighing $2.9 \mathrm{~kg}$ was $2 \times 15 \mathrm{mg}$. The recommended dose of cefixime is $8 \mathrm{mg} / \mathrm{kg} /$ day in divided doses for 12-24 hours with a maximum dose of $400 \mathrm{mg} /$ day (Lacy, et al., 2011). The dose that should be given to the patient is $23.2 \mathrm{mg} / \mathrm{day}$, but the dose received by the patient is $30 \mathrm{mg} /$ day. The administration of these antibiotics was not at the right dose, because the dose of cefixime obtained by the patient was more than the recommended dose. Too high doses could cause unwanted side effects and toxicity. Oppositely, if the dose is too low, the optimal therapeutic effect will not be achieved.

Irrational use of antibiotics is also quite a lot found in category III A (incorrect duration of administration). Based on the Ministry of Health (2011) the use of an antibiotic is divided into three therapeutic categories; empirical antibiotics (used within 48-72 hours for bacterial infections of unknown cause), definitive antibiotics (known causes, types and patterns of resistance), and prophylactic antibiotics ( to prevent infection). Duration of use of antibiotic therapy varies depending on the type and severity of the disease. Empirical use of antibiotics is 2-3 days and then an evaluation is carried out based on the patient's clinical condition, microbiological examination, laboratory examination and other supporting data (Ministry of Health Regulation, 2015). If within 2-3 days the patient has improved clinical condition, then the use of antibiotics continued until the infection sured. Meanwhile, if the 
patient does not improve clinical condition, then antibiotics could be changed according to the patient's clinical condition.

For example in the case of cefotaxime used for 12 days, but the clinical condition of the patient did not improve. The patient still had watery diarrhea more than 3 times a day and unstable fever. Based on Taketomo, et al. (2011) and the World Gastroenterology Organization (2012, cefotaxime duration of use is 3 to 5 days and is also based on the type of infection and its severity. The overlong use of antibiotics could increase the concentration of drugs in the blood so that there is a risk of toxicity and antibiotic resistance. The use of antibiotics for too long can also damage the development of normal flora in the body, making it difficult to control bacterial infections (Francino, 2016).

\section{Class and Type of Antibiotics}

There are several groups and types of antibiotics used both single and combination antibiotics in pediatric acute diarrhea patients hospitalized at Fatmawati Hospital for the period 2018 to 2019. The distribution and frequency can be seen in table 11 below:

Table 4 Classes and Types of Antibiotics for Inpatient Pediatric Acute Diarrhea at Fatmawati Hospital for the 2018-2019 Period

\begin{tabular}{l|c}
\hline \multicolumn{1}{c|}{ Type and Class of Antibiotic } & $\mathbf{n}(\%)$ \\
\hline First Generation of Cephalosporin & $1(0,95)$ \\
Cefadroxil & \\
\hline Third Generation of & \\
Cephalosporin & $17(16,19)$ \\
Cefixim & $40(38,10)$ \\
Cefotaxim & $26(24,76)$ \\
Ceftriaxon & $13(12,38)$ \\
Metronidazole & $1(0,95)$ \\
\hline Macrolide & \\
Azithromycin & $3(2,86)$ \\
\hline Combination & $4(3,81)$ \\
Cefotaxim and Metronidazole & \\
Ceftriaxon and Metronidazole & \\
\hline
\end{tabular}

Based on the table 4, that the class of antibiotics used were first-generation cephalosporins, thirdgeneration cephalosporins, macrolides, metronidazole, and combination antibiotics between thirdgeneration cephalosporins and metronidazole. According to WGO (2012) third generation 
cephalosporins and metronidazole are included in empiric therapy for acute diarrhea. Metronidazole is widely used for treatment of anaerobic bacterial infections because the side effects are quite low, while the third-generation cephalosporin antibiotics have a wider spectrum than the first and second generations, therefore the occurrence of resistance is considerably lower.

Based on Table 4, the use of macrolide antibiotics with the type of azithromycin is 1 prescription with a percentage of $0,95 \%$. According to WGO (2012), this type of antibiotic is included in the management of acute diarrhea due to infection as a first-line treatment for E. Coli and Champylobacter.

Combination antibiotics used in acute diarrhea pediatric are cefotaxime with metronidazole $(2,86 \%)$ ceftriaxone with metronidazole $(3.8 \%)$. These combination antibiotics both have a broad spectrum. Frequently, the purpose of combined antibiotics is to increase the activity (synergistically) and to inhibit or reduce the risk of developing bacterial resistancy.

\section{The Relationship between the Rationality of Antibiotic Use and Types of Antibiotics}

Based on the data results, it is known that mostly antibiotic used for acute diarrhea is rational (category 0 ). The irrational use of antibiotics is divided into the use of antibiotics that are not in the right dose, there is no indication for the use of antibiotics, there are antibiotics that are safer, cheaper and more effective, and the use of antibiotics is too short and too long. The most widely used class of antibiotics is third generation cephalosporins and the most widely used type of antibiotic is cefotaxime.

There is a significant relationship in the results of bivariate statistical tests with Chi-Square analysis between rationality used of antibiotics and the type of antibiotics. The type of antibiotic used affects the rationality of antibiotics since some people could experience bacterial resistance, and some are allergic to certain types of antibiotics. The type of antibiotic given must be based on the patient's clinical condition and the type of infection. In the patient's case with a fungal infection, it is better to give metronidazole instead of cefotaxime or ceftriaxone because these drugs are for bacteria and fungi. In the matter of given antibiotics are not under the type of infection suffered by the patient, the patient will not get the optimal therapeutic effect.

\section{The Effect of Confounding Variables on the Rationality of Antibiotic Use}

Factors that may affect the rationality of antibiotics are age, gender, length of hospitalization, polypharmacy, comorbidities, route of administration, and duration of antibiotic administration. The statistical tests with multiple logistic regression showed that only the route of administration had $=0.000$ $(\rho<0.05)$ as seen in table 4. It represents route of administration had a significant relationship to the rationality of antibiotic use. The results of this study are also in line with the evaluation of the use of antibiotics in stroke patients at Koja Hospital which found a relationship between rationality and the 
route of antibiotic administration with a p value of $<0.05$ (Fransiska Sitompul, Maksum Radji, Anton Bahtiar, 2016).

Since the route of administration is included in the assessment to see the rationality of using antibiotics, right route of drug administration could accelerate the patient's healing process, acquired a fast onset, good bioavailability and patient's clinical condition. In the case of patient experiences nausea, vomiting, or unconscious, it is recommended to give the drug through the intravenous route to receive treatment immediately. In addition, some drugs can be damaged or inactivated in the digestive tract or are not well absorbed, particularly to provide a fast response, the choice of an intravenous route is recommended.

The route of drug administration in this study was orally or intravenously. During the hospital stay, a change in the route of administration would be made such as a change from intravenous to oral and this is also often done if the patient needs to get antibiotics when discharged from the hospital but the use of antibiotics needs to be continued. The type of route conversion method divided into sequential, switch, or step down therapy (Lee B. Murdaugh, 2008). Several guidelines have been published to assist clinicians in converting the route of drug administration. This is useful to reduce the risk of drug inaccuracy due to the route of administration.

Rational drug might be reached if the patient gets the drug according to the needs of his clinical condition with the right duration of administration and the cheapest price (WHO, 2010). In the condition of patients in hospitals, intravenous administration is generally more often used, considering that drug onset is often expected to be achieved more quickly in addition to maintaining stable levels in the blood. In some children, oral administration also presents its own challenges because not all children would cooperate easily to take drugs. From this explanation, it could be seen that intravenous administration is in accordance with the needs of inpatients, especially pediatric inpatients.

Table 4. The Effect of Confounding Variables on the Rationality of Antibiotic Use in Inpatient Pediatric Acute Diarrhea Patients at Fatmawati Hospital for the 2018-2019 Period

\begin{tabular}{|c|c|}
\hline Confounding Factors & $\rho$ value \\
\hline Age & 0,37 \\
\hline Gender & 0,99 \\
\hline Length of stay & 0,87 \\
\hline Polipharmacy & 0,51 \\
\hline Comorbid & 0,08 \\
\hline Administration route & 0,00 \\
\hline Antibiotic duration & 0,11 \\
\hline
\end{tabular}


Based on table 4 other variables such as age (0.37); gender (0.99); length of hospitalization (0.87); polypharmacy (0.51); comorbid (0.08); and duration of antibiotic administration (0.11), has a value of $>0.05$, which means that there is no significant relationship with the rationality of antibiotic use. Although only the route of drug administration indicates a significant relationship, the results of a study conducted by (Mariska Dian. 2017) found a relationship between the rationality of antibiotic therapy and the length of stay in diarrhea patients aged 1-12 years in the hospital Islam Sultan Agung Semarang period 2016.

\section{CONCLUSION}

The results of drug use rationality using Gyssens method, rational antibiotics used (category 0) was $54.3 \%$ and irrational antibiotics were $45.7 \%$ with category IIA (inappropriate dose) at the most, amount as $20.9 \%$. The chi-square statistical analysis and multiple logistic regression showed a significant relationship between the rationality of antibiotics and route of administration $(\rho=0.000<0.05)$.

\section{REFERENCES}

Astaqauliyah. (2010). Keputusan Menteri Kesehatan Republik Indonesia Nomor 216/Menkes/SK/XI/2001, Tentang Pedoman Pemberantasan Penyakit Diare, Edisi kelima. Yogyakarta: Dinkes Kabupaten Bantul.

Badan Penelitian dan Pengembangan Kesehatan Departemen Kesehatan Republik Indonesia. (2008). Laporan Nasional Riset Kesehatan Dasar 2007. Departetemen Kesehatan RI

Dinas Kesehatan. (2017). Profil kesehatan provinsi DKI Jakarta Tahun 2017. Kementrian Kesehatan RI. Jakarta.

Dipiro, J. T., Talbert, R. L., Yee, G. C., Matzke, G. R., Wells, B. G., Posey, L. M. (2015). Pharmacotherapy a Pathophysiologic Approach, $9^{\text {th }}$ Ed. New York: The McGraw-Hill Companies.

Francino, M. P. (2016). Antibiotics and the Human Gut Microbiome: Dysbioses and Accumulation of Resistances. Frontiers in Microbiology, (6), 1-11.

Fransiska, S., Maksum, R., Anton, B. (2016). Evaluation of Antibiotic used with Gyssens Method on Stroke Inpatient at RSUD Koja using Retrospective Approach (KJS and BPJS period). Jurnal Kefarmasian Indonesia. 6 (1): 30-38.

International Vaccine Access Center. (2014). Pneumonia and Diarrhea Progress Report 2014. Baltimore: Johns Hopkins Bloomberg School of Public Health.

Jissa, M. C., Emmanuel, J. (2014). Switch over from intravenous to oral therapy: A concise overview. Journal of Pharmacology and Pharmacoterapeutics. 5(2): 83-87.

Kementrian Kesehatan Republik Indonesia. (2013). Riset Kesehatan Dasar 2013. Badan Penelitian dan Pengembangan Kesehatan. Kementrian Kesehatan Republik Indonesia, Jakarta.

Lacy, C. F., Amstrong, L. L., Goldman, M. P., Lance, L. L. (2010). Drug Information Handbook, $18^{\text {th }}$ edition, Lexi Comp, Amerika. 
Lee, B. M. (2008). Text Book of Competence Assessment Tools for Health-System Pharmacies $4^{\text {th }}$ ed. USA: ASHP Publication.

Mariska, Dian. (2017). Hubungan Rasionalitas Terapi Antibiotika dan Lama Rawat Inap pada Pasien Anak Terdiagnosa Diare di Instalasi Rawat Inap Rumah Sakit Islam Sultan Agung Semarang Periode 2016. Fakultas Kedokteran Unissula, Semarang.

Peraturan Menteri Kesehatan Indonesia. (2015). Program Pengendalian Resistensi Antimikroba di Rumah Sakit. Kementrian Kesehatan Indonesia, Jakarta.

Samani Nijamudin, Zhang Jingxiao, Yong-Jie Yin, et al. (2014). Zinc in The Manage, Diarrhoea in Children Under The Age of 5 Years A-Review. 2 (6).

Taketomo, C.K., Hodding, J.H., Kraus, D. M., (2001). Pediatric Dosage Handbook, $17^{\text {th }}$ edition. Lexi Comp: Amerika.

World Gastroenterology Organisation. (2012). Acute Diarrhea in Adults and Children: A Global Perspective, World Gastroenterology Organisation. UK

World Health Organisation. (2010). Rational use of Medicines. Available online at http://www.who.int/medicines/areas/rational_use/en/index.html. [Accessed januari 17,21]. 